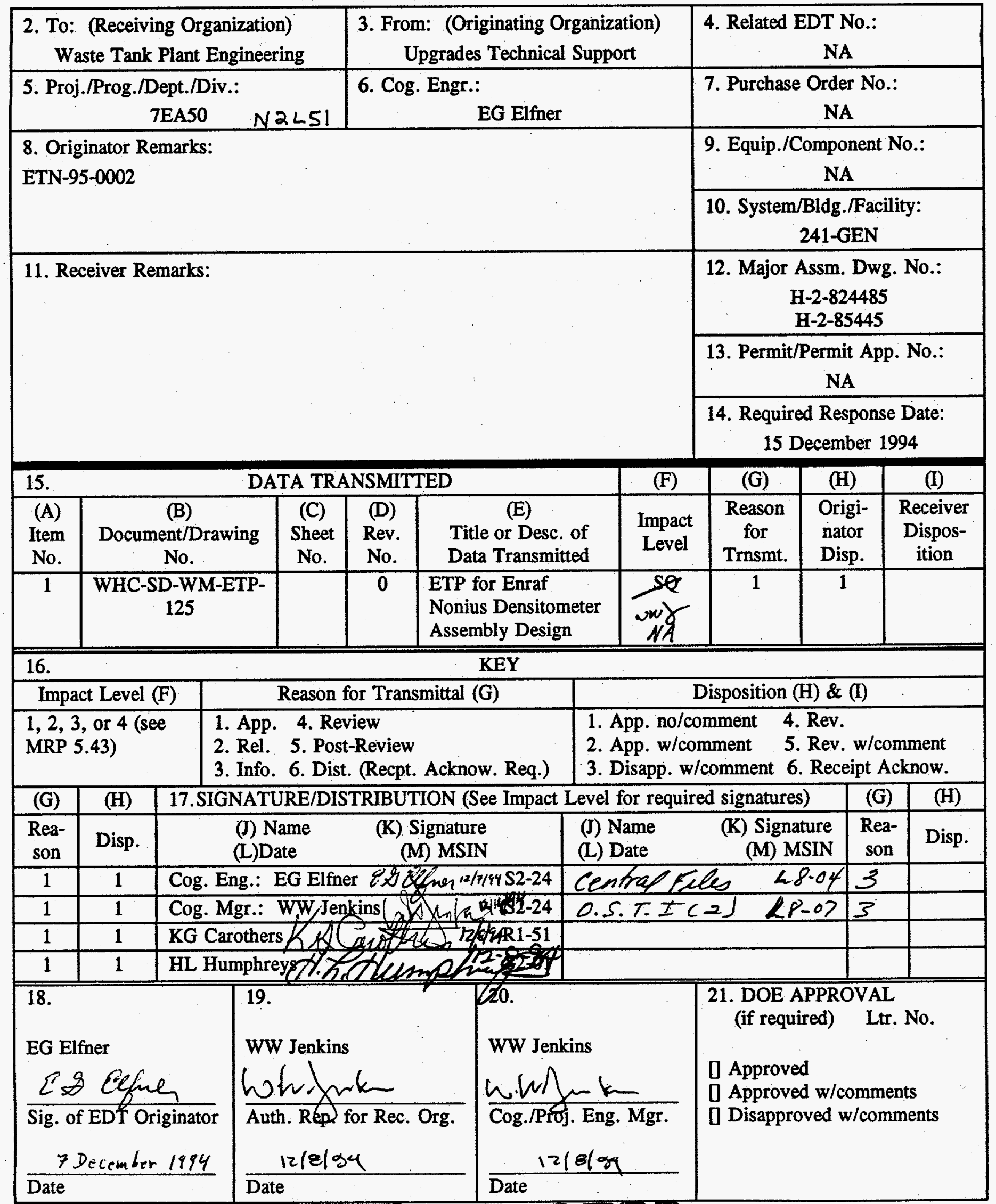




\section{DISCLAIMER}

Portions of this document may be illegible in electronic image products. Images are produced from the best available original document. 


\section{RELEASE AUTHORIZATION}

\begin{tabular}{|ll|}
\hline Document Number: & WHC-SD-WM-ETP-125, REV.0 \\
\hline Document Title: & $\begin{array}{l}\text { Engineering Task P1 an for Enraf Nonius Densitometer } \\
\text { Assembly Design }\end{array}$ \\
\hline Release Date: & December 13,1994 \\
\hline
\end{tabular}

This document was reviewed following the procedures described in WHC-CM-3-4 and is:

\section{APPROVED FOR PUBLIC RELEASE}

WHC Information Release Administration Specialist:

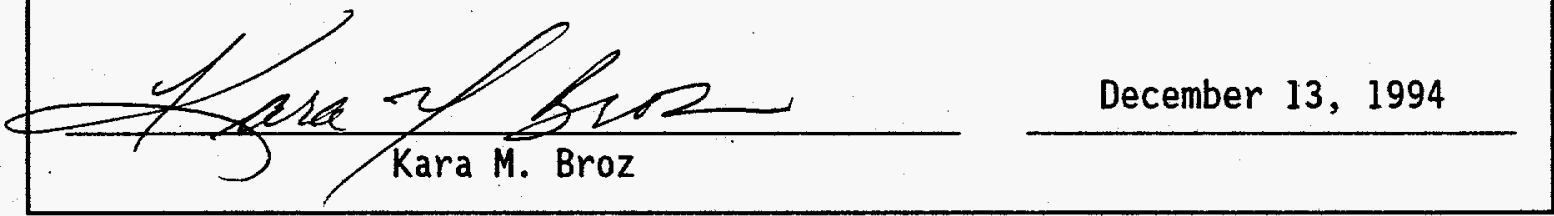

TRADEMARK DISCLAIMER. Reference herein to any specific commercial product, process, or service by trade name, trademark, manufacturer, or otherwise, does not necessarily constitute or imply its endorsement, recommendation, or favoring by the United States Government or any agency thereof or its contractors or subcontractors.

This report has been reproduced from the best available copy. Available in paper copy and microfiche. Printed in the United States of America. Available to the U.S. Department of Energy and its contractors from:

U.S. Department of Energy

Office of Scientific and Technical Information (OSTI)

P.0. Box 62

Oak Ridge, TH 37831

Telephone: (615) 576-8401

Available to the public from:

U.S. Department of Commerce

National Technical Information Service (NTIS)

5285 Port Royal Road

Springfield, VA 22161

Telephone: (703) 487-4650 
2. Title

Engineering Task Plan for Enraf Nonius Densitometer Assembly Design

\section{Key Words}

Ball Valve, Densitometer, Displacer, Enraf Nonius, Liquid Level Gauge, Rinse Spool Assembly, Sight Glass

\section{APPROVED FOR}

\section{TimB $12 / 13 / 94$ PUBLIC RELEASE}

3. Number

WHC-SD-WM-ETP-125

6. Author

Name: EG Elfner

Signature
4. Rev No.

$\mathbf{0}$

\section{Abstract}

A supporting assembly will be designed to accommodate the Enraf Nonius densitometer. The design will include a sight glass or calibration chamber, a rinse spool assembly, and a ball valve. The assembly will be based on the Enraf Nonius liquid level gauge assembly.

8. RELEASE STAMP

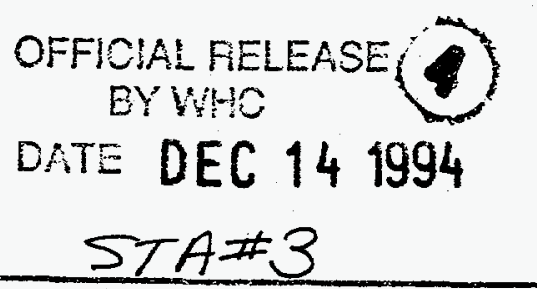


WHC-SD-WM-ETP-125

Revision 0

\title{
ENGINEERING TASK PLAN FOR ENRAF NONIUS DENSITOMETER ASSEMBLY DESIGN
}

\author{
7 December 1994
}

\author{
E. G. Elfner
}

\section{DISCLAIMER}

This report was prepared as an account of work sponsored by an agency of the United States Government. Neither the United States Government nor any agency thereof, nor any of their employees, makes any warranty, express or implied, or assumes any legal liability or responsibility for the accuracy, completeness, or usefulness of any information, apparatus, product, or process disclosed, or represents that its use would not infringe privately owned rights. Reference herein to any specific commercial product, process, or service by trade name, trademark, manufacturer, or otherwise does not necessarily constitute or imply its endorsement, recommendation, or favoring by the United States Government or any agency thereof. The views and opinions of authors expressed herein do not necessarily state or reflect those of the United States Government or any agency thereof. 
Table of Contents

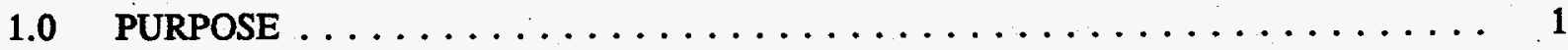

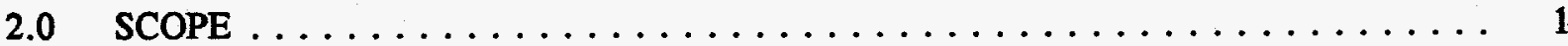

3.0 ENGINEERING TASKS $\ldots \ldots \ldots \ldots \ldots \ldots \ldots \ldots \ldots \ldots \ldots \ldots \ldots$

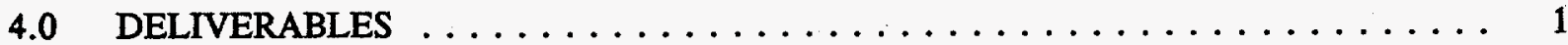

5.0 ORGANIZATION RESPONSIBILITIES $\ldots \ldots \ldots \ldots \ldots \ldots \ldots \ldots \ldots \ldots \ldots$

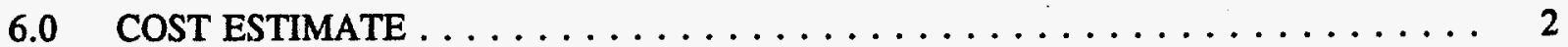

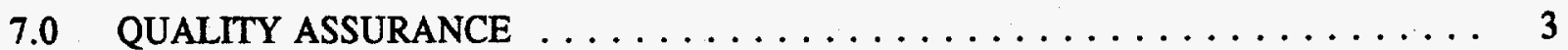

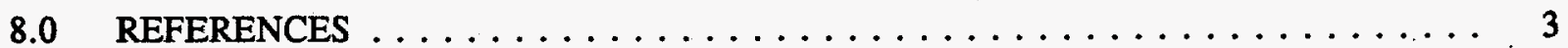


WHC-SD-WM-ETP-125

Revision 0

\section{ENGINEERING TASK PLAN FOR \\ ENRAF NONIUS DENSITOMETER ASSEMBLY DESIGN}

\subsection{PURPOSE}

The assemblies which support Enraf Nonius liquid level gauges require modification in order to be used with Enraf Nonius densitometers. The densitometers are upgraded versions of the liquid level gauge. They will initially be installed on Tank AN-107.

\subsection{SCOPE}

Final selection of the Enraf Nonius Densitometer instrument, as well as the ball valve which is located at the bottom of the assembly, has been made. The sight glass used with the liquid level gauge does not have an access port large enough to accommodate the densitometer displacer. This unit will need to be replaced with a suitable sight glass or with an Enraf Nonius Calibration Chamber. The rinse spool assembly which is used with the liquid level gauge will not adequately perform the task of rinsing the densitometer displacer and line. A new unit will have to be designed. The densitometer assembly design will be reviewed against the seismic analysis of the liquid level gauge to determine whether or not a new analysis is needed. A cost estimate for fabrication of two rinse spool assemblies will be obtained.

\subsection{ENGINEERING TASKS}

1. Select an appropriate sight glass or an Enraf Nonius Calibration Chamber for use with the densitometer.

2. Design a rinse spool assembly which will adequately rinse the densitometer displacer and line.

3. Provide information for new drawings of the rinse spool assembly and for installation of the densitometer assembly.

3. Review the densitometer assembly design against the seismic analysis of the liquid level gauge to determine whether or not a new analysis is needed.

4. Obtain a cost estimate for fabrication of two rinse spool assemblies.

\subsection{DELIVERABLES}

1. New drawings which depict installation of the densitometer assembly. 
WHC-SD-WM-ETP-125

Revision 0

2. New drawings which depict assembly of the rinse spool assembly.

3. New seismic analysis, if needed.

4. Cost estimate for fabrication of two rinse spool assemblies.

\subsection{ORGANIZATION RESPONSIBILITIES}

\section{Upgrades Technical Support:}

1. Prepare schedule for the design effort. Prepare cost estimates for the design effort. Determine safety classification and acceptance levels for documentation of the new assembly. Prepare supporting documentation and obtain approval.

2. Perform mechanical design for new instrument assembly. Have new drawings of the assembly prepared. Separate drawings will depict assembly and installation. The drawings will be produced as part of the existing design effort under which the densitometer electrical drawings are being produced.

3. Have the densitometer design reviewed, against that of the Enraf Nonius liquid level gauge, by the organization performing that analysis. Have new seismic analysis performed if required.

4. Obtain a cost estimate for fabrication of two rinse spool assemblies. This includes both the cost of shop materials and a labor breakdown of the hours required to build the assemblies.

Engineering Manager: WW Jenkins

Engineer: $\quad$ EG Elfner

\subsection{COST ESTIMATE}

The Rough Order of Magnitude estimate for the design of a new densitometer assembly is as provided below.

1. Design

- research/select components

7 days

- configure system

6 days

2. Seismic Analysis

- review

1 day

- perform calculations (if necessary)

1 day 
3. Documentation Preparation

- preparation

6 days

- review

1 day

- get comments and incorporate

4 days

- approval and release

2 days

4. Fabrication Cost Estimate (Rinse Spool Assembly) 2 days

Total: $\overline{30 \text { days }}$

Total Cost Estimate: $\$ 59.06 \times 224$ hours $=\$ 13,229.44$

Note: This is the cost if the seismic analysis is performed. If review determines that an analysis is not required, the cost will be somewhat lower.

\subsection{QUALITY ASSURANCE}

Quality Assurance (QA) for this effort will be in accordance with Reference 1. All documents produced will be reviewed in accordance with Reference 2 .

\subsection{REFERENCES}

1. WHC-CM-4-2, Quality Assurance Manual:

2. WHC-CM-3-5, Document Control and Records_Management Manual, Section 12.7, "Approval of Environmental, Safety, and Quality Affecting Documents". 